\title{
Enhancing natriuretic peptide bioactivity prevents bleomycin-induced pulmonary fibrosis
}

\author{
Reshma S Baliga ${ }^{1 *}$, Sarah L Trinder ${ }^{1}$, Christopher J Scotton², Rachel C Chambers ${ }^{2}$, Raymond J MacAllister ${ }^{3}$, \\ Adrian J Hobbs ${ }^{1,3}$
}

From 5th International Conference on cGMP: Generators, Effectors and Therapeutic Implications Halle, Germany. 24-26 June 2011

\section{Background}

Idiopathic pulmonary fibrosis (IPF) is a progressive fibro-proliferative disorder of unknown etiology, with no effective treatment regimen, and a median survival of just 3-5 years following diagnosis [1]. Pulmonary Hypertension (PH) often complicates IPF and is associated with higher mortality. Augmentation of endogenous natriuretic peptide (NP) stimulated cGMP, using a neutral endopeptidase inhibitor (NEPi) in combination with a phosphodiesterase 5 inhibitor (PDE5i), synergistically prevents pathogenesis in a hypoxic model of $\mathrm{PH}$ [2]. Herein, we assessed the efficacy of this novel NEPi/ PDE5i combination therapy in a model of pulmonary fibrosis.

\section{Methods}

Littermate wild-type (WT) and NP receptor-A knockout (NPR-A KO) mice (male; 20-25g; C57BLK6 background) were instilled with saline (control) or Bleomycin (Bleo; $1 \mathrm{mg} / \mathrm{kg}$ ) in the absence or presence of the PDE5i sildenafil $(30 \mathrm{mg} / \mathrm{kg} /$ day; p.o.) or the NEPi ecadotril $(60 \mathrm{mg} / \mathrm{kg} /$ day; p.o.). Haemodynamic and morphological parameters were measured 14 days post Bleo administration.

\section{Results}

Bleo treatment caused a significant rise in right ventricular systolic pressure (RSVP) in WT mice that was not reduced by either sildenafil or ecadotril alone, but significantly inhibited by the combination (Figure 1). Bleo administration also resulted in right ventricular hypertrophy $(\mathrm{RVH})$; this was prevented by treatment with sildenafil, ecadotril or the combination $(\mathrm{RV} / \mathrm{LV}+\mathrm{S}$; Control: 0.2486 \pm 0.005 , Bleo: 0.3054 \pm 0.0177 , Bleo+sildenafil: $0.258 \pm 0.006^{*}$, Bleo+ecadotril: $0.261 \pm 0.008^{*}$, Bleo+combination: $0.247 \pm 0.008$; ; $P<0.05$ versus Bleo).

Bleo instillation enhanced total lung collagen accumulation (index of fibrosis) which was ameliorated by concomitant administration of sildenafil, ecadotril or the combination (Control: $1.692 \pm 0.2$, Bleo: $4.4 \pm 0.35$, Bleo+combination: $2.124 \pm 0.12^{*}$; ${ }^{*} P<0.05$ versus Bleo).

NPR-A KO mice, lacking the bioactivity of ANP and BNP, exhibited an exaggerated haemodynamic response to Bleo (WT Bleo RSVP: $31.77 \pm 1.96 \mathrm{mmHg}$, KO Bleo RSVP: $41.68 \pm 2.78 \mathrm{mmHg} ; \mathrm{P}<0.05)$, and the beneficial effects of the combination therapy were lost (KO Bleo+combination RSVP: $39.84 \pm 2.41 \mathrm{mmHg}$; $P>0.05$ versus $\mathrm{KO}$ Bleo). A similar loss in efficacy of the combination treatment was observed against $\mathrm{RVH}$ (KO Bleo RV/LV+S: $0.252 \pm 0.008$, KO Bleo+combination RV/LV+S: $0.234 \pm 0.017 ; P>0.05)$. Figure 1.

\section{Conclusion}

The NEPi/PDE5i combination is effective in ameliorating both the haemodynamic aberrations and fibrotic lung disease in this model. This beneficial pharmacodynamic activity depends on the bioactivity of NPs, which represent an endogenous protective mechanism limiting disease progression. This work substantiates the therapeutic potential of manipulating NP and cyclic GMP signalling for $\mathrm{PH}$ and IPF.

\footnotetext{
* Correspondence: r.baliga@ucl.ac.uk

'Department of Pharmacology, University College London, Gower Street, London WC1E 6BT, UK

Full list of author information is available at the end of the article
} 
doi:10.1186/1471-2210-11-S1-P3

Cite this article as: Baliga et al:: Enhancing natriuretic peptide

bioactivity prevents bleomycin-induced pulmonary fibrosis. BMC

Pharmacology 2011 11(Suppl 1):P3.
Author details

'Department of Pharmacology, University College London, Gower Street, London WC1E 6BT, UK. ${ }^{2}$ Centre for Respiratory Research, University College London, Gower Street, London WC1E 6BT, UK. ${ }^{3}$ Centre for Clinical Pharmacology, University College London, Gower Street, London WC1E 6BT, UK.

Published: 1 August 2011

\section{References}

1. Eickelberg O, Selman M: Update in diffuse parenchymal lung disease 2009. Am J Respir Crit Care Med 2010, 181:883-888.

2. Baliga RS, Zhao L, Madhani M, Lopez-Torondel B, Visintin C, Selwood D, et al: Synergy between natriuretic peptides and phosphodiesterase 5 inhibitors ameliorates pulmonary arterial hypertension. Am J Respir Crit Care Med 2008, 178:861-869.
Submit your next manuscript to BioMed Central and take full advantage of:

- Convenient online submission

- Thorough peer review

- No space constraints or color figure charges

- Immediate publication on acceptance

- Inclusion in PubMed, CAS, Scopus and Google Scholar

- Research which is freely available for redistribution 